FisiPublik : Jurnal Ilmu Sosial dan Politik

https://journal.uwgm.ac.id/index.php/fisipublik

P-ISSN: 2528-2689; E-ISSN: 2540-9751

Vol 03 No 02 November 2018,

\title{
Kaderisasi Perempuan dalam Partai Politik untuk meningkatkan Partisipasi Perempuan di Kabupaten Ponorogo
}

\author{
Imam Sobari ${ }^{1}$, Robby Darwis Nasution², Khoirrurosyidin ${ }^{3}$ \\ ${ }^{123}$ Program Studi Ilmu Pemerintahan, Fakultas Ilmu Sosial dan Ilmu Politik, Universitas \\ Muhammadiyah Ponorogo \\ Email: imamsobari@gmail.com, darwisnasution69@gmail.com, rosyidin.kh@gmail.com
}

\begin{abstract}
Abstrak
Meski sudah ada payung hukum yang jelas mengenai keikutsertaan kaum perempuan dalam kancah politik tetapi masih sedikit sekali kaum perempuan yang berkecimpung dalam politik. Maka dari itu peneliti tertarik untuk meneliti tentang analisis pola kaderisasi perempuan partai GOLKAR dan PKB kabupaten ponorogo. Tujuan dari penelitian ini adalah untuk mngetahui bagaimana pola kederisasi perempuan pada partai GOLKAR dan PKB. Jenis peneilitian yang digunakan dalam penelitian ini adalah kualitatif. Metode yang diginakan dalam penelitian ini menggunakan teknik wawancara tersetruktur dan dokumentasi kemudian dianalisi dan dipaparkan dalam bentuk laporan. Hasil dari penelitian ini adalah partai GOLKAR maupun PKB mengagendakan program kaderisasi setiap lima tahun sekali, kaderisasi ini bersifat umum dan tidak ada kaderisasi yang kusus untuk perempuan. Belom ada AD/ART yang menyebutkan khusus tentang kaderisasi terhadap kaum perempuan. Rekrutmen partai bersifat terbuka artinya tidak kusus untuk kader partai tetapi terbuka untuk umum. Untuk bisa lebih meningkatkan keterwakilan perempuan seharusnya partai memasukkan aturan kusus untuk meningkatkan keterwakailan perempuan dalam AD/ART partai, kaum perempuan harus bisa menunjukkan kemampuannya kepada masyarakat sehingga bisa mendapatkan kepercayaan dari masyarakat, sebaiknya sistem rekrutmen bersifat tertutup sehingga memberikan kesempatan lebih kepada para kader.
\end{abstract}

Kata kunci: Kaderisasi, Partai Politik, Perempuan. 
FisiPublik : Jurnal IImu Sosial dan Politik

https://journal.uwgm.ac.id/index.php/fisipublik

P-ISSN: 2528-2689; E-ISSN: 2540-9751

Vol 03 No 02 November 2018,

\title{
Women in the Regeneration of Political Parties to Increase Female Participation in Ponorogo Regency
}

\begin{abstract}
Even though they were is a Rule of Law that clear about the participation of women in the political arena but still little women dabbling in politics. Therefore researchers interested to scrutinize about analysis pattern regeneration women GOLKAR and PKB Ponorogo Regency. The purpose of this research is to understand how pattern regeneration women at GOLKAR and PKB. The kind of research used in this research was qualitative. Methods used in this research using a technique interview structured and documentation of then analyzed and were presented in a form of Tthe report. The result of this research is GOLKAR and PKB regeneration for the program include, every five years regeneration was public and no regeneration. specifically for women. I Have not had the AD / ART particularly on regeneration against women. The party is open recruitment and does not specifically to party cadres and open to the public. To be able to generate a representation of women should be the party put certain rules to enhance representation of women in $\mathrm{AD} / \mathrm{ART}$, party women should be able to show his quality to the community so they can get trust from the community, better recruitment system is spatially closed so it gives more opportunity to cadres.
\end{abstract}

Keywords: Regeneration, Political Parties, Women. 
FisiPublik : Jurnal Ilmu Sosial dan Politik

https://journal.uwgm.ac.id/index.php/fisipublik

P-ISSN: 2528-2689; E-ISSN: 2540-9751

Vol 03 No 02 November 2018,

\section{Pendahuluan}

Undang-undang dasar (UUD) 1945 sebagai dasar negara pada hakikatnya bersifat demokratis, memberikan hak dan kesempatan yang sama bagi perempuan dan laki-laki untuk berperan dalam pembangunan. Pasal 27 ayat (1) UUD RI 1945 menegaskan bahwa: segala warga Negara bersamaan kedudukannya dalam hukum dan pemerintahan dan wajib menjunjung hukum dan pemerintahan itu dengan tidak ada kecualinya. Dari pasal ini jelas bahwasanya perempuan dan laki-laki tidak ada perbedaan hak dan kewajiban sedikitpun yang diatur dalam undangundang dasar. Karena baik laki-laki maupun perempuan adalah sama-sama warga negara seperti yang dijelaskan dalam pasal tersebut. Termasuk diantaranya adalah hak dalam hal berpolitik, baik laki-laki maupun perempuan juga sama kedudukannya. Meskipun demikian partasipasi kaum perempuan di Indonesia masih sangat kecil, terbukti dari sejak pertama kali diadakan pemilu tahun 1955 hingga yang terakhir tahun 2014 keterwakilan perempuan dilegislatif belum pernah mencapai angka 20\%, seperti yang dipublikasikan oleh Badan Pusat Statistik tertinggi yaitu pada tahun 2009 dengan jumlah keterwakilan perempuan sebesar 17,86\% (www.bps.go.id diakses pada 10 januari 2017).

Berbagai upaya sebenarnya telah dilakukan oleh pemerintah untuk menghilangkan diskriminasi terhadap kaum perempuan, selain yang dijelaskan dalam UUD pasal 27, Indonesia juga telah meratifikasi dua perjanjian, yaitu pertama perjanjian mengenai hak politik perempuan pada tahun 1952 telah diterima PBB dan diratifikasi oleh DPR menjadi UU No. 68 tahun 1958 yang pada pasal 1 menetapkan bahwa : perempuan berhak memberikan suara dalam semua pemilihan dengan status sama dengan pria tanpa diskrimminasi. Kedua Konvensi penghapusan Diskriminasi terhadap perempuan atau yang dikenal dengan CEDAW yang telah diterima oleh PBB tahun 1979 dan oleh DPR diratifikasi menjadi UU No. 7 tahun 1984, memberikan perlindungan terutama dibidang ketenagakerjaan (Budiardjo, 2010).

Sukses terbesar diperoleh ketika pemerintah mengesahkan UU Nomor 12 Tahun 2003 tentang Pemilu DPR, DPD, dan DPRD. Dalam undang-undang ini Peningkatan keterwakilan perempuan dilakukan dengan cara memberikan ketentuan agar partai politik peserta Pemilu memperhatikan keterwakilan perempuan sekurang-kurangnya 30\% di dalam mengajukan calon anggota DPR, DPD, dan DPRD. Pasal 65 ayat (1) UU Nomor 12 Tahun 2003 tentang Pemilu DPR, DPD, dan DPRD menyatakan: Setiap Partai Peserta Pemilu dapat mengajukan calon 
FisiPublik : Jurnal Ilmu Sosial dan Politik

https://journal.uwgm.ac.id/index.php/fisipublik

P-ISSN: 2528-2689; E-ISSN: 2540-9751

Vol 03 No 02 November 2018,

Anggota DPR, DPRD Provinsi, dan DPRD Kabupaten/Kota untuk setiap Daerah Pemilihan dengan memperhatikan keterwakilan perempuan sekurang-kurangnya 30\%(Budiardjo, 2010).

Dari waktu ke waktu, kebijakan tentang penghapusan diskriminasi terhadap perempuan dalam bidang politik atau kebijakan affirmatif semakin disempurnakan. Hal itu dapat ditelaah pada paket undang-undang yang digunakan pada pemilu tahun 2009, yaitu UU No. 22 Tahun 2007 tentang Penyelenggara Pemilu, UU No. 2 Tahun 2008 tentang Partai Politik dan UU No. 10 Tahun 2008 tentang Pemilu DPR, DPD, dan DPRD.

UU No. 22 Tahun 2007 tentang Penyelenggara Pemilu mengatur agar komposisi penyelenggara Pemilu memperhatikan keterwakilan perempuan minimal 30\%. Pasal 6 ayat (5) UU tersebut menyatakan bahwa : Komposisi keanggotaan KPU, KPU Provinsi, dan KPU Kabupaten/Kota memperhatikan keterwakilan perempuan sekurang-kurangnya 30\% (tiga puluh perseratus).

Pada UU No. 2 Tahun 2008 tentang Partai politik, kebijakan affirmatif dilakukan dengan mengharuskan partai politik menyertakan keterwakilan perempuan minimal 30\% dalam penidirian maupun dalam kepengurusan di tingkat pusat. UU No. 2 Tahun 2008 pada Pasal 2 tentang pendirian partai menyatakan: Pendirian dan pembentukan Partai Politik sebagaimana dimaksud pada ayat (1) menyertakan 30\% (tiga puluh perseratus) keterwakilan perempuan. Sedangkan masalah kepengurusan partai pada Pasal 20 UU No. 2 Tahun 2008 tentang Partai Politik disebutkan bahwa kepengurusan Partai Politik tingkat provinsi dan kabupaten/kota sebagaimana dimaksud dalam Pasal 19 ayat (2) dan ayat (3) disusun dengan memperhatikan keterwakilan perempuan paling rendah 30\% (tiga puluh perseratus) yang diatur dalam $\mathrm{AD}$ dan ART Partai Politik masing-masing, pada UU No. 10 Tahun 2008 tentang Pemilu Anggota DPR, DPD dan DPRD kebijakan affirmatif dilakukan dengan memberikan syarat kepada partai politik untuk bisa mengikuti pemilu jika telah menerapkan sekurang-kurangnya 30\% keterwakilan perempuan pada kepengurusannya di tingkat pusat dan mengharuskan daftar bakal caleg paling sedikit 30\%. keterwakilan perempuan. Penegasan tersebut diatur dalam UU No. 10 Tahun 2008 Pada Pasal 8 ayat (1) huruf d menyatakan bahwa: Partai Politik dapat menjadi peserta Pemilu setelah memenuhi persyaratan menyertakan sekurang-kurangnya 30\% (tiga puluh perseratus) keterwakilan perempuan pada kepengurusan partai politik tingkat pusat. 
FisiPublik : Jurnal Ilmu Sosial dan Politik

https://journal.uwgm.ac.id/index.php/fisipublik

P-ISSN: 2528-2689; E-ISSN: 2540-9751

Vol 03 No 02 November 2018,

Pasal 53 UU Pemilu No 10 Tahun 2008 menyatakan: Daftar bakal calon sebagaimana dimaksud pada Pasal 52 memuat paling sedikit 30\% (tiga puluh perseratus) keterwakilan perempuan. Sementara, ketentuan pada Pasal 52 mengatur mengenai daftar bakal calon anggota DPR, DPRD Provinsi dan DPRD Kabupaten/Kota yang ditetapkan oleh partai politik peserta Pemilu. Dengan demikian, kebijakan affirmatif keterwakilan perempuan dalam daftar bakal calon dilakukan tidak hanya untuk DPR, tetapi berlaku pula untuk DPRD Provinsi maupun DPRD Kabupaten/Kota. Meskipun pemerintah sudah berupaya sedemikian rupa dengan memberi wadah, member kesempatan yang begitu besar dengan membuat undang-undang yang sangat mendukung terhadap partisipasi perempuan dalam berpolitik, nyatanya masih sangat sedikit sekali partisipasi dari kaum perempuan. Ini terlihat dari keberadaan kaum perempuan dalam lembaga legislatif yang sangat minim dibandingkan dengan laki-laki. Jangankan untuk sampai pada 30\% seperti yang diinginkan oleh pemerintah dan ormas-ormas perempuan, untuk sampai pada $20 \%$ pun masih belum bisa. Bahkan pada pemilu terakhir yang dilakukan pada tahun 2014 kemarin seperti yang dipublikasikan oleh Badan Pusat Statistik malah menurun dari tahun sebelumnya, pada tahun 2009 keterwakilan perempuan sebesar 17,86\% pada pemilu tahun 2014 turun menjadi 17,32\%. Ini menunjukkan bahwa partisipasi dari kaum perempuan sangatlah kecil. (www.bps.go.id diakses pada 10 januari 2017).

Partisipasi kaum perempuan di kabupaten Ponorogo pun juga masih sangat minim, ini terbukti dari Keterwakilan perempuan dilembaga legislatif kabupaten Ponorogo yang masih sangat kecil. Dari analisis data yang dipublikasikan oleh Badan Pusat Statistik Ponorogo dari 50 kursi pada pemilu tahun 2009 hanya ada 8 dari kaum perempuan atau 16\%, sedangkan pada pemilu 2014 hanya tinggal 5 dari kaum perempuan menurun menjadi 10\% (ponorogokab.bps.go.id diakses pada 10 januari 2017)

Setelah berbagai upaya dilakukan oleh pemerintah untuk meningkatkan partisipasi kaum perempuan dan hasilnya tetap belum bisa mencapai target, tentunya giliran tugas partai politik untuk berupaya keras bagaimana agar bisa meningkatkan partisipasi perempuan di dunia perpolitikan Indonesia. Karena sesuai dengan yang diamanatkan oleh Undang-Undang No. 2 Tahun 2011 Tentang Partai Politik pasal 11, Partai Politik berfungsi sebagai sarana: Pertama, Pendidikan politik bagi anggota masyarakat luas agar menjadi warga negara Indonesia yang sadar akan hak dan kewajibannya dalam kehidupan bermasyarakat, berbangsa, dan bernegara. 
FisiPublik : Jurnal Ilmu Sosial dan Politik

https://journal.uwgm.ac.id/index.php/fisipublik

P-ISSN: 2528-2689; E-ISSN: 2540-9751

Vol 03 No 02 November 2018,

Kedua, Penciptaan iklim yang kondusif bagi persatuan dan kesatuan bangsa Indonesia untuk kesejahteraan masyarakat. Ketiga, Penyerap, penghimpun, dan penyalur aspirasi politik masyarakat dalam merumuskan dan menetapkan kebijakan negara. Keempat, Partisipasi politik rakyat Indonesia, dan yang Terakhir adalah Rekrutmen politik dalam proses pengisian jabatan politik melalui mekanisme demokrasi dengan memperhatikan kesetaraan dan keadilan gender. Selain mempunyai fungsi seperti yang disebutkan diatas Partai politik sebagai salah satu pilar demokrasi memiliki peran dalam memperdayakan dan meningkatkan perempuan dalam ranah publik maupun politik. Dalam Undang-Undang yang sama tentang partai politik yaitu undang undang No.2 Tahun 2011 pasal 34 ayat (3b) dinyatakan bahwa: "pendidikan politik sebagaimana dimaksud dalam ayat (3a) berkitan dengan kegiatan: Pertama Pendalaman mengenai empat pilar berbangsa dan bernegara yaitu Pancasila, UUD 1945, Bhineka Tunggal Ika dan Negara Kesatuan Republik Indonesia. Kedua, Pemahaman mengenai hak dan kewajiban negara Indonesia dalam pembangunan etika dan budaya politik. Dan yang terakhir Pengkaderan anggota partai politik secara berjenjang dan berkelanjutan"

Miriam fungsi partai politik meliputi sarana komunikasi politik, sarana sosialisasi politik, sarana rekrutmen politik dan sarana pengatur konflik (Budiarjo.2010), Menurut Roi C. Macridis yang fungsi partai politik adalah representasi (keterwakilan), konversi dan agregasi, integrasi (partisipasi, sosialisasi, mobilisasi), persuasi, represi, rekrutmen (pengangkatan tenaga-tenaga baru) dan pemilihan kebijaksanaan seta kontrol terhadap pemerinta (Ichlasul. 2012). Menurut Bambang Sunggono fungsi partai politik adalah sosialisasi politik, pendidikan politik, rekrutmen politik, komunikasi politik, artikulasi dan agregasi kepentingan serta pengatur konflik. Baik menurut undang-undang maupun para pakar ahli politik menyebutkan bahwa partai politik mempunya fungsi sebagai sarana pendidikan politik, sosialisasi politik dan rekrutment politik (Sunggono.1992).

Dari uraian diatas peneliti tertarik untuk meneliti dengan judul Kaderisasi perempuan dalam partai politik untuk meningkatkan partisipasi perempuan di kabupaten Ponorogo (studi kasus di Partai GOLKAR dan PKB kabupaten Ponorogo). Berdasarkan uraian yang telah di definisikan di atas, maka rumusan masalah dari penelitian ini adalah: Bagaimanakah kaderisasi perempuan pada partai GOLKAR dan PKB kabupaten Ponorogo dalam meningkatkan partisipasi perempuan dalam dunia politik? 
FisiPublik : Jurnal Ilmu Sosial dan Politik

https://journal.uwgm.ac.id/index.php/fisipublik

P-ISSN: 2528-2689; E-ISSN: 2540-9751

Vol 03 No 02 November 2018,

\section{Metodologi}

Penelitian ini merupakan penelitian yang dimaksudkan untuk menyimpulkan informasi mengenai status suatu gejala yang ada, yaitu keadaan gejala menurut apa adanya pada saat penelitian diadakan Penelitian ini merupakan penelitian deskriptif kualitatif, yaitu mendiskripsikan suatu gejala atau gambaran yang kompleks yang terjadi saat ini. Maka dalam penelitian ini berusaha untuk menyajikan deskripsi mengenai pola kaderisasi partai politik dalam pemenuhan kuota perempuan dalam legislatif Kabupaten Ponorogo.

Penelitian ini dilakukan di kabupaten Ponorogo. Peneliti memilih lokasi tersebut karena dari hasil pemilu dua periode terakhir, yaitu tahun 2009-2014 dan periode 2014-2019 keterwakilan perempuan dilembaga legislatif kabupaten hanya sebesar 16\% pada tahun 2009 dan menurun diperiode tahun 2014 tinggal sebesar 10\% (ponorogokab.bps.go.id).

Dalam pemilu legislatif tahun 2014 di Ponorogo diikuti 12 partai yaitu Partai Nasional Demokrat (NASDEM), Partai Kebangkitan Bangsa (PKB), Partai Keadilan Sejahtera (PKS), Partai Demokrasi Indonesia Perjuangan (PDIP), Partai Golongan Karya (Golkar), Partai Gerakan Indonesia Raya (GERINDRA), Partai Demokrat, Partai Amanat Nasional (PAN), Partai Persatuan Pembangunan (PPP), Partai Hati Nurani Rakyat (Hanura), Partai Bulan Bintang (PBB), Partai Keadilan dan Persatuan Indones ia (PKPI ). Namun dari 12 partai tersebut hanya 10 partai yang mendapatkan kursi DPRD Ponorogo yaitu semua partai diatas kecuali Partai Bulan Bintang (PBB) dan Partai Keadilan dan Persatuan Indonesia (PKPI). Dan dari sepuluh partai yang mendapatkan kursi itu ada 4 partai yangmempunyai keterwakilan perempuan yaitu, GOLKAR, PAN, GEINDRA, dan PDI-P (Ponorogo dalam angka 2015).

Tabel 1

Daftar Informan dari Pengurus Partai GOLKAR

\begin{tabular}{|c|l|c|ll|}
\hline No & \multicolumn{1}{|c|}{ Nama } & Jenis Kelamin & \multicolumn{1}{|c|}{ Jabatan } \\
\hline 1 & Joko Susilo & Laki - laki & Wakil Ketua Bidang Pemuda \& Olahraga \\
\hline 2 & Drs. Ahmad Fauzi & Perempuan & Wakil Sekertaris II & \\
\hline 3 & Winingsih & Laki - laki & $\begin{array}{l}\text { Bendahara dan juga Anggota DPRD } \\
\text { Ponorogo }\end{array}$ \\
\hline
\end{tabular}

Sumber : diolah dari hasil penelitian 
FisiPublik : Jurnal Ilmu Sosial dan Politik

https://journal.uwgm.ac.id/index.php/fisipublik

P-ISSN: 2528-2689; E-ISSN: 2540-9751

Vol 03 No 02 November 2018,

Tabel 2

Daftar Informan dari Pengurus Partai PKB

\begin{tabular}{|c|l|l|l|}
\hline No & \multicolumn{1}{|c|}{ Nama } & \multicolumn{1}{c|}{ Jenis Kelamin } & \multicolumn{1}{c|}{ Jabatan } \\
\hline 1 & $\begin{array}{l}\text { Dwi Agus } \\
\text { Prayitno }\end{array}$ & Laki - laki & Sekretaris dewan tanfidz \\
\hline 2 & $\begin{array}{l}\text { Binti Akhlaqil } \\
\text { Mukaromah, }\end{array}$ & Perempuan & Wakil Ketua dewan tanfidz \\
\hline
\end{tabular}

Sumber : diolah dari hasil penelitian

Dalam hal penelitian data sangatlah penting, supaya hasil penelitiannya bisa dipertanggungjawabkan. Data adalah segala keterangan (informasi) mengenai semua hal yang Berkaitan dengan tujuan penelitian (Idrus, 2009). Teknik pengumpulan data dalam kegiatan penelitian ini, 1). Wawancara mendalam adalah proses memperoleh keterangan untuk tujuan penelitian dengan cara tanya jawab sambil bertatap muka antara pewawancara dengan informan atau orang yang diwawancarai, dengan atau tanpa menggunakan pedoman (guide) wawancara, dimana pewawancara dan informan terlibat dalam kehidupan sosial yang relatif lama. Dengan demikian, kekhasan dalam wawancara mendalam adalah keterlibatannya dalam kehidupan informan (Bungin, 2009), 2). Dokumentasi adalah metode pengumpulan data kualitatif dengan melihat dan menganalisis dokumen-dokumen yang telah dibuat oleh orang lain. Dokumentasi adalah mencari data mengenai hal-hal atau variabel yang berupa catatan, transkip, buku, surat kabar, majalah, prasasti, notulen rapat, lengger, agenda dan sebagainya (Suharsimi, 2006), Dokumentasi dalam hal ini adalah dokumen-dokumen yang terkait tentang partai GOLKAR dan PKB kabupaten Ponorogo, data tersebut berupa buku AD, ART, buku saku anggota partai dan lain-lain yang ada kaitannya dengan penelitian ini.

Tahap akhir proses pengumpulan data adalah verifikasi dan penarikan kesimpulan, yang dimaknai sebagai penarikan arti data yang telah ditampilkan. Babarapa cara yang dapat dilakukan dalam proses ini adalah dengan melakukan pencatatan untuk pola-pola dan tema yang sama, pengelompokan, dan pencarian kasus-kasus negatif (kasus khas, berbeda, mungkin pula menyimpang dari kebiasaan yang ada di masyarakat) (Idrus, 2009). Dari pengertian di atas dalam menganalisis data yang diperoleh setelah melalui tahap pengumpulan data, langkah berikutnya penulis menganalisis data yang diperoleh dari lapangan dengan pendekatan deskriptif kualitatif 
FisiPublik : Jurnal Ilmu Sosial dan Politik

https://journal.uwgm.ac.id/index.php/fisipublik

P-ISSN: 2528-2689; E-ISSN: 2540-9751

Vol 03 No 02 November 2018,

yaitu cara berfikir induktif dimulai dari analisis sebagai data yang terhimpun dari suat penelitian, kemudian menuju kearah kesimpulan.

\section{Pembahasan dan Analisis Data}

Dari hasil wawancara dan dokumentasi yang telah peneliti dapatkan menunjukkan bahwa partai PKB dan partai GOLKAR adalah partai seperti yang telah didefinisikan oleh undangundang No. 2 tahun 2011 yaitu organisasi yang bersifat nasional dan dibentuk oleh sekelompok warga negara Indonesia secara sukarela atas dasar kesamaan kehendak dan cita-cita untuk memperjuangkan dan membela kepentingan politik anggota, masyarakat, bangsa dan negara, serta memelihara keutuhan Negara Kesatuan Republik Indonesia berdasarkan Pancasila dan Undang- Undang Dasar Negara Republik Indonesia Tahun 1945.

Partai PKB dan Golkar telah melaksanakan fungsinya sesuai dengan yang diamanatkan oleh undang-undang No. 2 tahun 2011 yang dalam penelitian ini fokus pada pendidikan politik bagi anggota masyarakat luas agar menjadi warga negara Indonesia yang sadar akan hak dan kewajibannya dalam kehidupan bermasyarakat, berbangsa, dan bernegara, Partisipasi politik rakyat Indonesia, dan Rekrutmen politik dalam proses pengisian jabatan politik melalui mekanisme demokrasi dengan memperhatikan kesetaraan dan keadilan gender.

Pola kaderisasi yang dilakukan oleh partai PKB dan partai GOLKAR dalam mencari kader partai yaitu dengan mengadakan pendidikan semacam diklat yang sudah diagendakan oleh partai dari tingkat pusat dan diatur dalam anggaran dasar maupun anggaran rumah tangga partai. Pengkaderan atau diklat yang dilakukan adalah tentang pendidikan dan pelatihan, penanaman idiologi partai pengenalan partai pendidikan tentang kepemimpinan dan lain sebagianya dan ditutup dengan kegiatan pelantikan kader baru.

Pola kaderisasi yang dilakukan partai Golkar maupun PKB dalam mengkader kaum perempuan yaitu dengan mewajibkan peserta kaderisasi minimal 30\% dari kaum perempuan. Golkar mengamanatkan keterwakilan 30\% yang mengikuti kaderisasi itu kepada pengurus kecamatan, sedangkan PKB hanya mewajibkan peserta yang hadir pada kegiatan kaderisasi harus 30\%. Selain itu Golkar maupun PKB membentuk organisasi perempuan untuk mencari kader perempuan, Golkar mempunyai 2 organisasi perempuan yaitu Himpunan Wanita Karya(HWK) dan Ikatan Istri Partai Golkar(IIPG) sedangkan PKB mempunyai 1 organisasi khusus perempuan 
FisiPublik : Jurnal Ilmu Sosial dan Politik

https://journal.uwgm.ac.id/index.php/fisipublik

P-ISSN: 2528-2689; E-ISSN: 2540-9751

Vol 03 No 02 November 2018,

yaitu Perempuan Bangsa. Artinya partai PKB dan GOLKAR telah melaksanakan fungsi partai sebagai organisasi seperti yang diungkapkan oleh Russel J.Dalton dan Martin P. Wattenberg (Sigit, 2012).

Pada fungsi ini menunjuk pada fungsi-fungsi yang melibatkan partai sebagai organisasi politik, atau proses-proses didalam organisasi partai itu sendiri. Pada bagian ini partai politik memiliki 4 (empat) fungsi, yaitu: Rekrutmen kepemimpinan politik dan mencari pejabat pemerintahan, Pelatihan elit politik, Pengartikulasian kepentingan politik dan Pengagresian kepentingan politik.

Rekrutmen pada partai GOLKAR maupun PKB dalam mencalonkan anggota legislatif yang akan mengikuti pemilu bersifat terbuka artinya tidak kusus bagi kader partai tetapi juga untuk masyarakat umum yang dinilai mampu untuk bersaing pada pilihan legislatif. Hambatan yang dialami partai GOLKAR dalam meningkatkan keterwakilan perempuan dilembaga legislatif adalah pertama ketakutan dari diri perempuan sendiri untuk memasuki dunia politik, sehingga partisipasi kaum perempuan dalam politik masih sangat minim. Kedua, tidak adanya dukungan dari keluarga si perempuan bahkan adanya larangan dari kelurga untuk menggeluti dunia politik dan yang Ketiga masalah biaya yang digunakan untuk biaya politik. Sedangkan hambatan yang dialami partai PKB adalah masalah agama dan budaya masyarakat Ponorogo yang lebih mengutamakan laki-laki dari pada perempuan dalam masalah pemimpin. Tetapi masalah budaya lebih kuat pengaruhnya dalam penentuan pilihan masyarakat untuk pemimpin mereka dari pada masalah agama.

\section{Kesimpulan}

Kesimpulan yang bisa diambil dalam penelitian ini adalah Partai GOLKAR maupun PKB mengadakan pengkaderan yang sudah diagendakan secara rutin oleh partai. Pola Pengkaderan dilakukan dengan mengadakan diklat pendidikan kepada kader partai. Dalam partai GOLKAR diklat pendidikan ini dinamakan KARAKTERDES sedangkan pada PKB diklat pendidikan dilakukan secara berjenjang mulai dari pendidikan kader pertama (PKP), pendidikan kader menengah (PKM), dan terakhir ada pendidikan kader atas (PKA). Pengkaderan pada partai GOLKAR dilakukan setiap lima tahun sekali setelah MUSDA, sedangkan untuk partai PKB dilakukan setiap lima tahun sekali untuk tingkat cabang tetapi pengurus cabang mengagendakan 
FisiPublik : Jurnal Ilmu Sosial dan Politik

https://journal.uwgm.ac.id/index.php/fisipublik

P-ISSN: 2528-2689; E-ISSN: 2540-9751

Vol 03 No 02 November 2018,

sendiri pengkaderan untuk anak cabang setiap tahun sekali dengan wilayah yang berbeda-beda sesui daerah pemilihan pada pemilu legislatif.

Pola kederisasi yang dilakukan yang dilakukan oleh partai Golkar maupun partai PKB yaitu mengadakan kaderisasi secara serentak baik itu untuk laki-laki maupun perempuan. Tidak ada kaderisasi yang dilakukan oleh partai GOLKAR maupun partai PKB yang khusus untuk perempuan. Partai GOLKAR maupun partai PKB member wadah untuk mengkader perempuan dengan mendirikan organisasi sayap atau badan otonom. Partai GOLKAR mendirikan HWK himpunan wanita karya dan IIPG ikan istri partai GOLKAR sedangkan partai PKB mendirikan Perempuan Bangsa untuk wadah kader bagi perempuan. Perbedaan pola kaderisasi dari kedua partai yang digunakan untuk meningkatkan keterwakilan perempuan adalah partai GOLKAR memiliki dua organisasi sayap khusus untuk perempuan sedangkan partai PKB hanya satu, dalam kegiatan kaderisasi partai GOLKAR menyerahkan peserta perempuan yang mengikuti kegiatan kaderisasi kepada pengurus cabang wilayah Kecamatan (DPC), Sedangkan dalam partai PKB tidak ada pembagian tugas rekrutment khusus untuk perempuan baik ditingkat Kabupaten (DPC) maupun tingkat Kecamatan (DPAC) yang penting kuota dalam kaderisasi telah memenuhi $30 \%$.

Dalam rekrutmen calon legislatif partai GOLKAR maupun partai PKB menggunakan sistem terbuka artinya tidak khusus untuk kader partai tetapi dibuka untuk umum. Meski pola yang digunakan kedua partai hampir sama tetapi mempunyai pengaruh yang berbeda dalam keterwakilan perempuan dilegislatif kabupaten Ponorogo. Golkar sebagai partai tertinggi perolehannya di Kabupaten Ponorogo memiliki 2 keterwakilan perempuan dilembaga legislatif sedangkan partai PKB yang berada diurutan kedua sama sekali tidak memiliki keterwakilan perempuan dilembaga legislatif kabupaten Ponorogo. Hambatan yang dialami partai GOLKAR maupun partai PKB dalam meningkatkan keterwakilan perempuan dilembaga legislatif adalah pertama ketakutan dari diri perempuan sendiri untuk memasuki dunia politik, sehingga partisipasi kaum perempuan dalam politik masih sangat minim. Kedua, tidak adanya dukungan dari keluarga si perempuan bahkan adanya larangan dari kelurga untuk menggeluti dunia politik dan yang Ketiga masalah biaya yang digunakan untuk biaya politik. Keempat, masalah agama dan budaya masyarakat Ponorogo yang lebih mengutamakan laki-laki dari pada perempuan dalam masalah pemimpin. 
FisiPublik : Jurnal Ilmu Sosial dan Politik

https://journal.uwgm.ac.id/index.php/fisipublik

P-ISSN: 2528-2689; E-ISSN: 2540-9751

Vol 03 No 02 November 2018,

\section{Daftar Pustaka}

Amal, Ichlasu. (2012).Teori-Teori Mutakhir Partai Politik. Yogyakarta. Tiara Wacana.

Arikunto, suharsimi. (2006) Prosedur Penelitian Suatu Pendekatan Praktik. Jakarta: PT Rineka Cipta.

Budiardjo, Miriam. (2010). Dasar-Dasar Ilmu Politik. Jakarta : PT Gramedia Pustaka Utama.

Budiardjo, Miriam. (1998). Partisipasi dan Partai Politik Sebuah Bunga Rampai. Jakarta : Yayasan Obor Indonesia.

Bungin, Burhan.( 2009). Penelitian Kualitatif Komunikasi, Ekonomi, Kebijakan publik, dan ilmu sosial lainnya. Jakarta: Kencana Prenada Media Grub.

Idrus, Muhammad. (2009). Metode Penelitian Ilmu Sosial. Yogyakarta: Erlangga.

Pamungkas, Sigit. (2012). Partai Politik Teori dan Praktik di Indonesia. Yogyakarta. Institute For Democrasy and Welfarism.

Sunggono, Bambang. (1992) Partai Politik Dalam Kerangka Pembangunan di Indonesia. Surabaya. PT Bina Ilmu.

https://ponorogokab.bps.go.id/linkTabelStatis/view/id/178 diakses pada 5 januari 2017

https://ponorogokab.bps.go.id/website/pdf_publikasi/Ponorogo-Dalam-Angka-2015.pdf diakses pada 5 januari 2017

https://www.bps.go.id/linkTabelStatis/view/id/1172 diakses pada 4 januari 2017

UU No. 10 Tahun 2008 tentang Pemilu DPR, DPD, dan DPRD.

UU No. 2 Tahun 2008 tentang Partai Politik

UU No. 2 Tahun 2011 Tentang Partai Politik

UU No. 22 Tahun 2007 tentang Penyelenggara Pemilu

UUD 1945 